\title{
Tephra Geochemistry Confirms the Caldera-forming Eruption of Aniakchak, not Santorini, at 1645 BC
}

W.J. Eastwood ${ }^{1 *}$, N.J.G. Pearce ${ }^{2}$, J.A. Westgate ${ }^{3}$, S.J. Preece ${ }^{3}$, and W.T. Perkins ${ }^{2}$

${ }^{1}$ School of Geography, Earth and Environmental Sciences, University of Birmingham, B15 2TT, U.K; W.J.Eastwood@bham.ac.uk 2Institute of Geography and Earth Sciences, University of Wales, Aberystwyth, SY23 3DB, U.K.

${ }^{3}$ Department of Geology, University of Toronto, Ontario, M5S 3B1, Canada.

*INQUA Sub-Commission for Tephrochronology and Volcanism (SCOTAV)

One of the most powerful volcanic eruptions known to have occurred during the Holocene was the midsecond millennium $B C\left(\sim 3300{ }^{14} \mathrm{C}\right.$ yr BP) 'Minoan' eruption of Santorini (orThera) in the southern Aegean Sea. Much controversy surrounds inferred cultural and environmental impacts attributed to the Santorini eruption; notable among these are mid-second millennium BC climatic variations, as manifested by anomalous tree-ring growth rates and acidity peaks registered in ice-cores from Greenland. One such acidity peak attributed to the Santorini eruption, and recorded in the Dye 3 and GRIP ice cores from Greenland, is dated to 1645 BC. In order to link a particular eruption with the ice core record, one must first find and analyze juvenile volcanic materials, then correlate these elemental analyses with known sources. Hammer et al. (2003) claim that glass shards recovered from the GRIP ice core from Greenland confirm a $1645 \pm 4 \mathrm{BC}$ age for the Minoan eruption of Santorini. Here we summarize the results of our tephrochronological analyses on Aniakchak (Alaskan) tephra (Pearce et al., 2004) and compare these with the reinterpreted data of Hammer et al. (2003). We propose that the eruption of Aniakchak, not Santorini, can be correlated to the 1645 BC acidity spike.

Hammer et al. (2003) produced major-element data using an analytical scanning electron microscope (ASEM) and trace-element data by ion microprobe (SIMS) to compare the ice-core glass (A1340-7) with the Minoan (Bo-1) glass from Santorini. Despite large analytical errors on their ASEM analyses, and considerable compositional differences in many elements $\left(\mathrm{SiO}_{2}, \mathrm{FeO}_{\mathrm{t}}, \mathrm{MgO}\right.$, $\mathrm{Ba}, \mathrm{Sr}, \mathrm{Rb}, \mathrm{Sm}, \mathrm{Nb})$, these samples were considered to be equivalent. Their analyses of Minoan glass

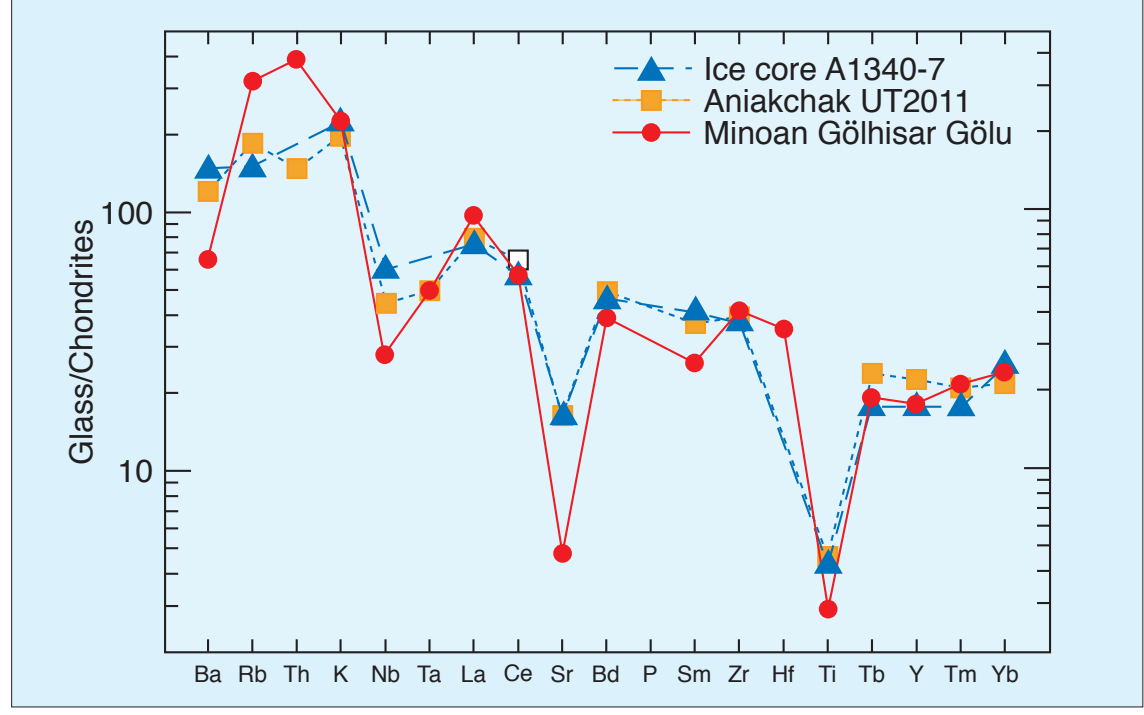

Fig. 1: Chondrite normalized incompatible element spidergram for glass from the GRIP ice core (A1340-7; Hammer et al., 2003), the Minoan tephra deposited at Gölhisar Gölü, SWTurkey (Pearce et al., 2002) and Aniakchak tephra (UT2011; Pearce et al., 2004). (Normalization factors from Thompson (1982)).

(Bo-1) are similar to our analyses of Minoan glass from a sediment core retrieved from Gölhisar Gölü, a small intramontane lake in SWTurkey (Pearce et al., 2002; Eastwood et al., 1999). However, the Turkish data show considerable differences with the ice-core glass. Because of the large number of major-element analyses by Hammer et al. (2003), it was possible to compare directly their ice-core glass composition (by ASEM) with that of other tephras (by EPMA) by recalibrating the ice-core data using the relationship between the Bo-1 data from Hammer et al. (2003) and Minoan glass from Gölhisar Gölü (Eastwood et al., 1999).

We also compared the Hammer et al. (2003) ice-core data with North American eruptions and found that the Aniakchak tephra (UT2011) and the ice core glass (A1340-7) are extremely similar with only minor differences $(<8 \%$ relative) for all elements except $\mathrm{FeO}_{\mathrm{t}}$ (25\% relative difference). In all cases, the 1 $\sigma$ error on the ASEM analyses of A1340-7 encompasses the analysis of UT2011. The major-element data strongly suggest that the glass in the ice core is derived from Aniakchak; the glass shard data from the other North American sources all have very different compositions.

Hammer et al. (2003) also produced SIMS trace-element analyses of 8 glass shards from the A1340-7 ice core sample and compared these with 3 analyses of glass from the Bo-1 sample. Unfortunately, the analysis of only 3 grains of $\mathrm{Mi}$ noan (Bo-1) material is statistically insufficient to gain an impression of the accuracy of the SIMS analyses when the heterogeneity of the Minoan pumice, as shown by the large inter-shard variation described recently by Pearce et al. (2002), is considered. Despite this, their traceelement analyses for the Bo-1 glass are broadly comparable with other published analyses of Minoan material for many elements (Pearce et al., 2002; Eastwood et al., 1999). As with the major elements, there are again considerable differences between the two sets of data in the Hammer et al. paper, with factors of up to 2.6 for differences in $\mathrm{Sr}$, around 1.5 for $\mathrm{Ba}, \mathrm{Sm}, \mathrm{Nd}$ and $\mathrm{Rb}$ and around 1.2 


\section{Science Highlights: Tephra}
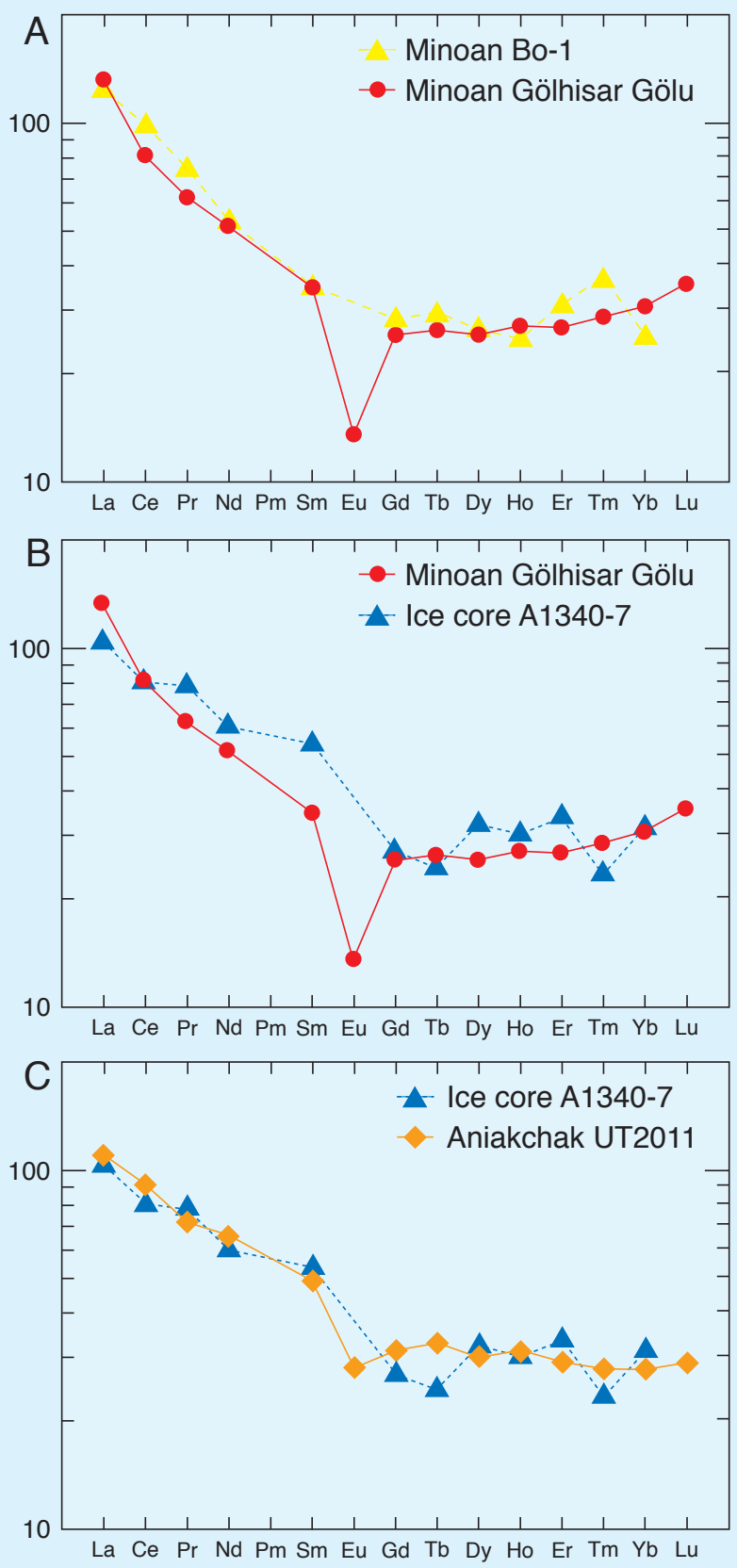

Fig. 2: Chondrite normalized REE spidergrams for glass from the GRIP ice core (A1340-7: Hammer et al., 2003), the Minoan Bo-1 deposit on Santorini (Hammer et al., 2003), the Minoan tephra deposited at Gölhisar Gölü, Turkey (Pearce et al., 2002) and tephra from the calderaforming eruption of Aniakchak (UT2011; Pearce et al., 2004). (Normalization factors from Sun, S.-S. and McDonough, W.F. (1989)

for the LREE (lighter rare earth elements). Once again, in tephra studies, differences in trace element concentrations of this magnitude rule out a possible correlation. At the reported concentrations (a few 10 to a few $100 \mathrm{ppm}$ ), elements such as $\mathrm{Ba}, \mathrm{Sr}, \mathrm{Rb}$ and the LREE should be determined with accuracy and precision (perhaps around $\pm 10 \%$ ) The differences between the Bo-1 and A1340-7 analyses are well beyond any realistic analytical errors and far too great for these deposits to be considered the same. The differences between A1340-7 and the Minoan ash is further highlighted when they are compared with the 56 single glass shard analyses of the Minoan ash performed by laser ablation ICP-MS (Pearce et al., 2002). The most apparent differences are in the concentrations of $\mathrm{Ba}, \mathrm{Sr}, \mathrm{Rb}$ (Fig. 1) and the LREE (Fig. 2), where it is clear that the REE concentrations determined by Hammer et al.
(Bo-1) and Pearce et al. (Gölhisar Gölü) for the Minoan deposit are similar (Fig. 2a), but that there is a marked difference in slope between the Minoan sample and the ice core glass, which has a much lower La/ Sm ratio (Fig. $2 b$ ).

Trace element data for the Aniakchak tephra (UT2011) has almost identical $\mathrm{Sr}, \mathrm{Rb}, \mathrm{Zr}$, REE values to A1340-7, as well as very similar Ba, $\mathrm{Nb}, \mathrm{Y}$ and $\mathrm{Cs}$ values (Fig. 1), particularly if some allowance is made for the possible differences in the SIMS analyses of Bo-1 when compared to other analyses of Minoan tephra (Pearce et al., 2002; Eastwood et al., 1999). In Figure 2c, the Aniakchak REE analyses are compared with the ice core A1340-7 analyses, where it is evident that the two data sets have an indistinguishable REE profile. The incompatible element spidergram (Fig. 1) compares the Minoan and Aniakchak tephras with the ice core glass. The Aniakchak tephra and A1340-7 glass are essentially identical, and these both have markedly different $\mathrm{Rb}, \mathrm{Sr}, \mathrm{Ba}$, $\mathrm{Ti}$, and $\mathrm{Sm}$ values from the Minoan tephra.

The trace element analyses concur with the major-element analyses and also rule out the suggested correlation between the ice core glass and Santorini. Instead, they show that the A1340-7 glass was derived from Aniakchak. The chronology of the ice core as defined by Hammer et al. (2003) thus places a firm date of $1645 \pm 4$ BC on the caldera-forming eruption of Aniakchak. This is also consistent with the suggestion that the acid volcanic signal recorded in the GRIP, North Grip and Dye 3 ice cores is the result of a major volcanic eruption south of Greenland but north of $30^{\circ} \mathrm{N}$ (Hammer et al., 2003). The presence of glass shards trapped within the ice core in this case directly link the Aniakchak eruption with the acid peak at 1645 BC. While this does not rule out a coincidental eruption of Santorini, it casts severe doubt on the proposed $1645 \mathrm{BC}$ age for the Minoan eruption. Whilst this identification provides an accurate and precise age for the Aniakchak eruption, and a source for one of 
the acid spikes in the Greenland ice cores, our results have two important implications: (i) they leave the controversy about the age of the Minoan eruption unresolved, and (ii) they suggest that the acid spike cannot be attributed to the Santorini Minoan eruption, and therefore the environmental perturbation(s) caused by this eruption were most probably not as widespread or as significant as previously envisaged (Eastwood et al., 2002).

\section{Acknowledgements}

We would like to thank Jim Beget for pro- viding the sample of Aniakchak tephra. This work was supported by research grants from the Natural Sciences and Engineering Research Council, Canada to JAW.

\section{REFERENCES}

Eastwood, W.J., Pearce, N.J.G., Westgate, J.A. Perkins, W.T., Lamb, H.F. and Roberts, N. 1999: Geochemistry of Santorini tephra in lake sediments from southwest Turkey. Global and Planetary Change, 429, 17-29.

Eastwood, W.J., Tibby, J.C., Roberts, N., Birks, H.J.B. and Lamb. H.F., 2002: The environmental impact of the Minoan eruption of Santorini (Thera) numerical analysis of palaeoecological data from Gölhisar, southwest Turkey. The Holocene, 12(4), 431-444.

Hammer, C.U., Kurat, G., Hoppe, P. Grum, W. and

Clausen, H.B., in press: Thera eruption date 1645

$\mathrm{BC}$ confirmed by new ice core data? Proceedings of SCIEM2000 (Synchronisation of Civilisations in the Eastern Mediterranean in the $2^{\text {nd }}$ Millennium BC), pp. 87-94

Pearce, N.J.G., Eastwood, W.J., Westgate, J.A. and Perkins, W.T. (2002) The composition of juvenile volcanic glass from the Minoan eruption of Santorini (Thera), c.3300 BP. Geological Society Special Publication, 159, 545-556.

Pearce, N.J.G., Westgate, J.A., Preece, S.J., Eastwood, W.J. and Perkins, W.T. (2004) Identification of Aniakchak (Alaska) tephra in Greenland ice core challenges the 1645 BC date for Minoan eruption of Santorini. Geochemistry Geophysics Geosystems, 5. (www.agu.org/journals/gc/).

For full references please consult:

www.pages-igbp.org/products/newsletters/ref2004_3.html

\section{Last Glacial Sea-Levels Reconstructed by Buried Fluvial Terraces and Tephrochronology in a Pacific Coast Plain, Japan}

\section{S. KUBO}

Department of Geography, School of Education, Waseda University, Tokyo 169-8050, Japan; sumik@waseda.jp

\section{Introduction}

Japanese paleoenvironmental sciences that include tephrochronological studies make a significant contribution to studies of sea-level change during the Last Glacial period. The study here highlights the contribution that Late Pleistocene tephrochronological studies make to a synthesis of findings about past sea-level fluctuations in the Lower Sagami Plain.

Millennial-to-centennial scale climatic fluctuations in the Last Glacial period can be detected in ice-cores (Stuiver and Grootes, 2000) and there is evidence that these are paralleled by changes in sea-level. As a result, much is still to be discovered about eustatic global sea-level changes and corresponding changes in ice volume during parts of the last Glacial period (van Andel, 2002). In coastal areas, however, it is often hard to obtain evidence of sea-levels during the Pleistocene period, as suitable material for study may be submerged or buried under younger deposits.

The small, steep coastal Lower Sagami river plain lacks a distinct continental shelf, therefore changes in sea-level can cause a flight of terraces to form. Tephra layers in deposits from the Lower Sagami Plain provide the means to correlate the formation of the terraces. The area is well-suited to studies that in-

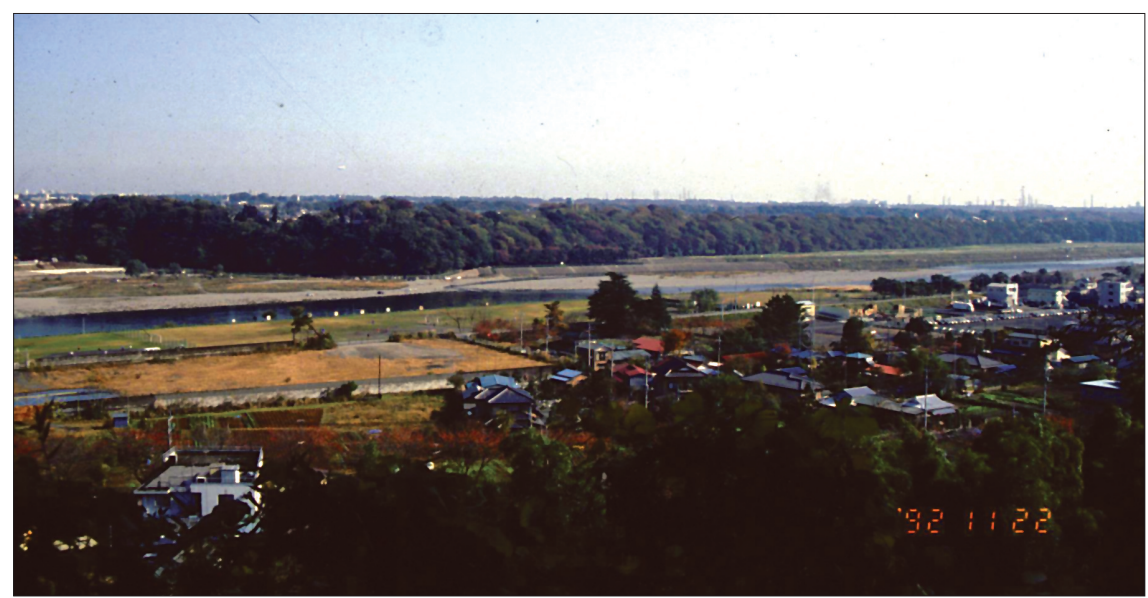

Fig. 1: Sagami River and its terraces. Minahara (MIS 2) and Tanahara (MIS 3) terraces (back) are steeper than the present river bed (front). Terraces are covered with volcanic ash soil.

corporate tephrochronology of Fuji and Hakone Volcanoes for the Last Glacial Cycle.

\section{Study Site and Methodology}

The Lower Sagami Plain has well-developed marine and fluvial terraces and the mouth of the Sagami River (drainage area $=1,680 \mathrm{~km}^{2}$ ) faces the ocean trough at a point where there is no distinct continental shelf. The Sagami River has been repeatedly sensitive to past sea-level changes. More than fifteen subaerial terraces from the Last Glacial Cycle can be identified in the lower Sagami Plain, including the Koza (K), Sagamihara $(\mathrm{S})$, Nakatsuhara (N), Tanahara (T) and Minahara (M) terraces. Collectively, these form the Sagamino Upland, from the mouth of the river to about $30 \mathrm{~km}$ upstream. The average gradient of the present Sagami River is $2.4 \times 10^{-3}$ in this section, although most of the upper terraces are steeper (Fig. 1).

The Fuji and Hakone Volcanoes are the major sources of tephra in the terraces. The dates of the major marker tephras have been obtained by fission-track, thermoluminescence, electron spin resonance, $\mathrm{K}-\mathrm{Ar}$ and 14C. Additionally, the widespread AT (circa $25 \mathrm{ka}$ ) and Aso-4 (circa $90 \mathrm{ka}$ ) tephras also provide age controls. In the plain, deposition is roughly continuous and the average accumulation rate of volcanic ash soil during the last $100 \mathrm{ka}$ is $0.22 \mathrm{~m} / \mathrm{kyr}(22$ $\mathrm{m} / 100 \mathrm{ka})$. A multi-proxy approach that included tephrostratigraphy, pollen stratigraphy, and correlation 